\title{
What Does Competence Mean?
}

\author{
Käthe Schneider \\ Friedrich Schiller University of Jena, Jena, Germany \\ Email:k.schneider@uni-jena.de
}

How to cite this paper: Schneider, K. (2019). What Does Competence Mean? Psychology, 10, 1938-1958.

https://doi.org/10.4236/psych.2019.1014125

Received: October 30, 2019

Accepted: November 26, 2019

Published: November 29, 2019

Copyright () 2019 by author(s) and Scientific Research Publishing Inc. This work is licensed under the Creative Commons Attribution International License (CC BY 4.0).

http://creativecommons.org/licenses/by/4.0/

\begin{abstract}
In recent decades, there has been growing interest in competence in Educational and Psychological Research and Human Resource Development Studies. One of the reasons for the popularity of competence research is the functional perspective of competence and the endeavor to further it. However, despite numerous studies on competence, the ambivalence of the concept of competence makes it hard to evaluate research findings. The aim of the present study is to make a contribution to the conceptual clarification of competence. We have made a systematic literature review and as part of it applied constructive analysis in the field of the concept of competence to postulate a new relation and broaden the conceptual theory of competence. We made our systematic literature review using the EBSCO host Library database and Google Scholar. Based on specific search criteria and on the sub-processes of the constructive analysis, we carried out the systematic review of the 10 identified definitions. Although we did not find a definition that we can employ according to our known use of other terms, we identified the meanings of construct, ability, and quality as plausible. Embedded within the etymological reconstruction, the logical conceptual systems of educational science and psychology and representative philosophical analyses, we state the new conceptual relation of competence.
\end{abstract}

\section{Keywords}

Competence, Ability, Domain-Specificity, Systematic Literature Review, Conceptual Analysis, Constructive Analysis

\section{Introduction}

The concept of competence that White (1959) introduced into the scientific discussion of motivational psychology six decades ago, in thinking about drive-reduction theory and psychoanalytic-instinct theory, as a "motivational concept" (p. 318), is today increasingly a research topic in other disciplines such 
as educational science and business administration. Almost ten years after the introduction of the concept of competence in psychology, Chomsky in 1968 distanced himself in his linguistic theory from the then prevailing behavioristic linguistics, which equated language with observable sound and sentence patterns, by introducing the technical term of linguistic competence in connection with language acquisition (Chomsky, 1965: p. 4). Chomsky (1965: p. 4) assumes an inherited cognitive system, a system of knowledge and beliefs developed in early childhood, which underlies linguistic accomplishments.

However, the concept of competence has a much longer history of technical meanings than that of psychology and linguistics: in jurisprudence, this concept can be traced back to Roman law (Fügemann, 2004: p. 140).

Not only have the disciplinary perspectives on the subject of competence expanded, but so has interest in competence in various sentence systems, such as educational policy and pedagogical practice, as shown by the institutionalization of comparative educational analyses by the OECD, for example, to measure the performance capacity of national educational systems.

White (1959: p. 297) defines competence as “... an organism's capacity to interact effectively with its environment...”. One of the most influential definitions was developed in the OECD DeSeCo-Project ${ }^{1}$ in line with Weinert's definition of competence: "A competence is defined as the ability to meet individual or social demands successfully, or to carry out an activity or task" (OECD, 2002: p. 8).

Despite numerous studies of competence, there are, however, a considerable number of authors who complain about the ambivalence of the concept of competence (e.g., Blömeke, Gustafsson, \& Shavelson, 2015; Hoffmann, 1999; Jacques, 2016; Klieme \& Hartig, 2008; Short, 1985; Stoof et al., 2002; Velde, 1999; Wilhelm \& Nickolaus, 2013). For example, Weinert comments "that the many implicit (in word use) and explicit (in theoretical frames of reference) definitions of competence are so heterogeneous that only a small, vague conceptual core remains" (Weinert, 1999: p. 26). Or it is for Ashworth and Saxton (1990, p. 3) “... not clear whether a competence is a personal attribute, an act, or an outcome of action...".

Besides the variety of meanings of competence, there are two different concepts in Britain and America, competence in Britain and competency in America according to Mitchelmore \& Rowley (2010): While competence refers to behavior a person should be able to demonstrate (e.g. Moore et al., 2002), competen$c y$ is defined as an underlying set of personal characteristics that facilitate superior performance (e.g. Boyatzis, 1982, 2008)².

The ambiguity of the concept of competence is a problem despite the currently frequent employment in science, educational policy and practice which burdens scientific communication and makes it impossible to evaluate research findings (Hartig, 2008). Despite more than five years of intensive research stu-

\footnotetext{
${ }^{1}$ The OECD DeSeCo project provides a theoretical foundation for identifying competences needed for a Successful Life and a Well-Functioning Society in modern democratic societies (OECD, 2002).

${ }^{2}$ The concept of competency will not be included in this conceptual analysis.
} 
dies in the area of competence, there are only a few conceptual analyses of the concept of competence in studies. Among the studies focusing on competence there are some literature reviews (Fügemann, 2004; Hoffmann, 1999; Klieme \& Hartig, 2008; Müller-Ruckwitt, 2008; Norris, 1991; Roeger, 2016; Short, 1985; Stoof et al., 2002; Weinert, 1999) of the many scientific uses of the terms "competence".

In Table 1, we compiled an overview of the essential results of the reviews of literature. Based on the initial analysis of these literature reviews, Table 1 shows as a result that the different definitions of competence are characterized by controversy, ambiguity, and contradiction. Although we can find some identical higher-order concepts, a broad range of different higher-order concepts and characteristic features characterizes the current state of research.

Considering the analyzed positions of competence, we can identify the following incompatible concepts that have been associated with competence: behavior vs. ability, inherited vs. learned, observable vs. non-observable, motivational vs. cognitive, quality vs. state, specific vs. general disposition, cognitivist vs. behavioristic construct, objectivist vs. constructivist view, construct vs. non-construct.

That the meanings of the term competence differ depending on the purpose for which it is used (Hoffmann, 1999: p. 275) contributes to the viewpoint that a generally valid definition of competence that would satisfy scientific criteria is not a realistic goal (Hartig, 2008). Stoof et al. (2002), who use the constructivist approach, confirm this perspective. For another reason, we can find a critical position towards the term competence: “...'competence' is the embodiment of a mechanistic, technically-oriented way of thinking which is normally inappropriate to the description of human action, or to the facilitation of the training of human beings". (Ashworth \& Saxton, 1990: p. 24) Viewed from a philosophical perspective, Roeger (2016) also regards analysis of the concept of competence as impractical, because the concept is "technical" (p. 110).

The goal of the present study is to contribute to the conceptual clarification of competence by systematically reviewing the literature on the concept of competence. With the aid of conceptual analysis, the concept of competence will be explained. The outcome of this review should be to provide a framework of the higher-order concept and the differentia specifica of competence. A conceptual clarification of the concept of competence makes possible the construction of a coherent research program which is founded on an unambiguous and unified conceptual system.

\section{Method}

To analyze definitions of competence we made a systematic literature review. As part of it, we employed conceptual analysis to identify the higher-level concept and specific conceptual characteristics.

To do our systematic literature review, we used the EBSCO host Library (http://www.ebscohost.com/) database and additionally Google Scholar 
Table 1. Reviews of literature including the categories of definitions of the terms competence.

\begin{tabular}{|c|c|}
\hline Authors/Year & Results \\
\hline $\begin{array}{l}\text { Fügemann } \\
\text { (2004) }\end{array}$ & $\begin{array}{l}\text { - Responsibility (legal perspective) } \\
\text {-Effective power to act of institutions that determines according to the } \\
\text { fulfillment of a specific task the means available" (p. 146) } \\
\text { (legal perspective) }\end{array}$ \\
\hline $\begin{array}{l}\text { Hoffmann } \\
\text { (1999) }\end{array}$ & $\begin{array}{l}\text { - Observable performance/standard or quality of the outcome of the } \\
\text { performance (output-based "in making the demonstration of competent } \\
\text { performance an ... observable measure of human performance") (p. 284) } \\
\text { - Underlying attributes of a person (input-based to design instruction) }\end{array}$ \\
\hline $\begin{array}{c}\text { Klieme \& } \\
\text { Hartig (2008) }\end{array}$ & $\begin{array}{l}\text { - Jurisdiction and disposal over means of enforcement } \\
\text { (Sociology Max Weber), } \\
\text { - Universal, inherited modularized ability to acquire the mother tongue } \\
\text { (Linguistics. Chomsky), } \\
\text { - Learnable context-specific performance dispositions that relate } \\
\text { functionally to situations and demands in specific domains } \\
\text { (pragmatic-functional psychology). }\end{array}$ \\
\hline $\begin{array}{l}\text { Müller-Ruckwitt } \\
\quad(2008)\end{array}$ & $\begin{array}{l}\text { - Coincide/coincidence } \\
\text { - Targeting } \\
\text { - } \text { Ability to objectify (through general claim juristically grounded } \\
\text { - } \text { entitlement } \\
\text { - Responsibility } \\
\text { - } \quad \text { Harmitted action space (reference object) }\end{array}$ \\
\hline Norris (1991) & $\begin{array}{l}\text { - Behaviorist construct: Description of behavior and the situation in which } \\
\text { it takes place } \\
\text { - Generic construct: general abilities } \\
\text { - Cognitive construct }\end{array}$ \\
\hline $\begin{array}{c}\text { Roeger } \\
(2016 \text {, p. } 159)\end{array}$ & $\begin{array}{l}\text { Subject-specific ability to reliably fulfill subject-specific demands under } \\
\text { normal circumstances. }\end{array}$ \\
\hline Short (1985) & $\begin{array}{l}\text { - Behavior or performance (a logical or empirical connection between } \\
\text { specific behavior or performances and some unit of competence must be } \\
\text { demonstrated (this conception not employed) } \\
\text { - Command of knowledge or skills (not easy to determine what knowledge } \\
\text { and skills persons require if they are to be competent) } \\
\text { - Degree or level of capability deemed sufficient (in case of complex action } \\
\text { difficult value judgment) } \\
\text { - Quality of a person or as a state of being (when the quality being judged } \\
\text { is fully explicated and justified, is a simple and objective process) }\end{array}$ \\
\hline $\begin{array}{l}\text { Stoof et al. } \\
\quad(2002)\end{array}$ & $\begin{array}{l}\text { - Objectivist point of view. Criteria: truth of definition } \\
\text { - Constructivist point of view. Criteria: viability of definition: Extent to } \\
\text { which the constructed definition has proved to be adequate in the context } \\
\text { in which it is used. }\end{array}$ \\
\hline Weinert (1999) & $\begin{array}{l}\text { - Intellectual abilities: general and domain-specific (general psychological } \\
\text { dispositional construct), } \\
\text { - Cognitive abilities, skills, knowledge, strategies, routines necessary for } \\
\text { mastering specific demands, expectations and performance criteria } \\
\text { (specific performance disposition), } \\
\text { - Motivation: subjective estimation of personal performance resources and } \\
\text { related motivational action tendencies. }\end{array}$ \\
\hline
\end{tabular}

Source: Own analysis of reviews of literature. 
(https://scholar.google.de) to search for articles using the core search terms: competence, Kompetenz and compétence. We selected the EBSCO host Library, because this database has meta-data of more than 64,000 journals. Google scholar was used because it is regarded as the worldwide largest academic web search engine.

As a scientific method to clarify the concept, we employed conceptual analysis (Nuopponen, 1998). Its function is to clarify the contents of concepts, as well as their relations to other concepts (Nuopponen, 1998).

In the frame of conceptual analysis, Kosterec (2016: p. 222) uses three methods: Constructive Analysis, Detection Analysis and Retention Analysis. In Constructive Analysis, a new relation is postulated, or it is stated that "some already known relation holds among previously unrelated parts of the language" (Kosterec, 2016: p. 222), whereas Detection Analysis studies the existence of a conceptual relation in implicit conceptual theory. While in both methods the relations of a single conceptual network are studied, in Reductive Analysis the relation between two conceptual networks is analyzed (Kosterec, 2016).

We applied Constructive Analysis in the field of the concept of competence to postulate a new relation and broaden the conceptual theory of competence (Kosterec, 2016).

Following Kosterec (2016), Constructive Analysis consists of the following steps:

- Specifying the initial conceptual background CB,

- Formulating the conceptual problem $\mathrm{P}$,

- Stating the new conceptual relation $\mathrm{R}$,

- Formulating tests $\mathrm{T}$ of the conceptual relation $\mathrm{R}$ within $\mathrm{CB}$,

- Elaborating the new relation $\mathrm{R}$ by tests $\mathrm{T}$ respecting $\mathrm{CB}$, and

- If the relation $\mathrm{R}$ succeeds in tests, declaring it a part of $\mathrm{CB}$.

The search procedure consists of three steps. In the first step, we selected databases referenced in the EBSCO host Library of the disciplines Business/Economics, Education and Psychology \& Sociology. All available databases of the respective disciplines were included. To specify the advanced search, the following search criteria were set in EBSCO: Search within the 1) title 2) the full text of the articles, 3) and scholarly (peer reviewed) journals, 4) find all my search terms. In the second step of the search procedure, we selected literature referenced in Google Scholar. Finally, in the third step, we excluded from the conceptual analysis a) exact duplicates, b) articles with reference to specific competences such as for example communicative competence, and c) articles that did not include these types of information "Oberbegriff" (higher-level concept) of competence and "differentia specifica" after reading the abstracts resp. the papers.

We conducted these search and exclusion processes, which was done on 7 May 2019, with these inclusion/exclusion criteria (see Table 2).

Applying these inclusion and exclusion criteria, we reached a number of 10 
Table 2. Literature search procedure within EBSCO host library databases and Google scholar.

\begin{tabular}{|c|c|c|c|}
\hline Process & Terms & $\begin{array}{c}\text { Databases/search } \\
\text { engine }\end{array}$ & Matches \\
\hline
\end{tabular}

Step 1

Search 1: Specific terms in English,

French and

German

Search 2: Specific terms in English,

French and

German

Step 2

Search 1: Specific terms in English,

French and

German

Search 2: Specific terms in English, French and

German

- "concept analysis

of competence",

- "Begriffsanalyse von

Kompetenz",

- "analyse

conceptuelle de compétence"

- "definition of competence",

- "Definition von

Kompetenz"

- "définition de

compétence"
- concept analysis and of and competence $(\mathrm{N}=20)$

EBSCO Host

Library databases

- Begriffsanalyse and von and Kompetenz $(\mathrm{N}=0)$

- analyse conceptuelle and de and compétence $(\mathrm{N}=0)$

- definition and of and competence $(\mathrm{N}=15)$

EBSCO Host

Library databases - Definition and von and Kompetenz $(\mathrm{N}=0)$

- définition and de and compétence $(\mathrm{N}=1)$

Google Scholar

Google Scholar

- concept analysis of competence

$(\mathrm{N}=125)$

- Begriffsanalyse von

Kompetenz $(\mathrm{N}=0)$

- analyse conceptuelle de compétence

$(\mathrm{N}=0)$

- definition of competence

$(\mathrm{N}=7.110)$

- Definition and von and Kompetenz $(\mathrm{N}=705)$

- définition and de and compétence $(\mathrm{N}=310)$

\section{Step 3}

Search excluding

- exact duplicates,

- specific

competences,

- lack of

higher-level

concept

- lack of differentia

specifica

Source: Own analysis.

Total:

- English: $\mathrm{N}=9$

- French: N = 1 
selected articles, of which nine were in English and one article in French. Based on the six sub-processes of the conceptual analysis, we conducted the systematic review of the 10 articles (see Table 3 ).

\section{Results}

\subsection{Specifying the initial conceptual background CB}

To specify the initial conceptual background CB we etymologically derived the concept of competence and created a characteristic matrix with the higher-level concepts and the differentia specifica of competence in the definitions of the identified 10 articles.

\section{Etymological Background}

The word competentia goes back to the present participle active form of the verb competere (Eykmann, 2016: p. 34). The verb competere "... is a combination of the preposition used as a prefix 'cum' (= mit) and the stem word 'petere' (= to achieve, seek, strive for), thus 'competere' = collectively set out for a goal; coincide, come together". (Eykmann, 2016: p. 34) In a Latin etymological dictionary by Walde (1954) we find under the entry-petō, in the simplex form, the translated meanings: to try to achieve; to hurry, strive, request, demand; apply for. "The intransitive 'competere' is used in the simple spatial sense (come together, go together, meet) and in the simple temporal sense (come together, coincide)". (Eykmann, 2016: p. 34)

Behse (1976) observes that in Classical Latin the concept of competentia was used in the original sense of meet, come together. Derived from this basic meaning are as adjective or participle the substantively related meanings of suitable and appropriate (Eykmann, 2016: p. 34). "The substantive 'competentia', is documented only since the second century $\mathrm{AD}$, is derived from the ... intransitive use of the verb, and its somewhat rare use is limited to a few technical terms: in mathematics 'proportion', in astronomy 'constellation/conjunction', otherwise, e.g., the 'symmetry' of the body's limbs" (Eykmann, 2016: p. 34). In a Medieval Latin dictionary that includes Latin sources from the ninth to the end of the twelfth century, under the key word competentia are the meanings fit together, correspondence, appropriateness, suitability, fittingness (Schmidt, 1999).

Table 3. Identified literature based on search procedure within EBSCO host library databases and Google scholar.

\begin{tabular}{cc}
\hline Authors/Year & Authors/Year \\
\hline Blömeke et al. (2015) & Klieme et al. (2008) \\
Eraut (1998) & Mulder (2011) \\
Fernandez et al. (2012) & Short (1985) \\
Hager \& Gonczi (1996) & Velde (1999) \\
Jacques (2016) & Weinert (1999) \\
\hline
\end{tabular}

Source: Own analysis. 
The meanings in legal language range from the revenue of an ecclesiastical office that could be shown for the seventeenth century to judicial power in the eighteenth century, to responsibilities in the nineteenth century (Fügemann, 2004: p. 140). In the course of Germanization activities in the nineteenth century, the concept of Kompetenz was replaced by the concept of Zuständigkeit (responsibility, jurisdiction), so that today the concept no longer plays a role in the language of German legislators (Fügemann, 2004: p. 135).

Even if we can agree with Eykmann (2016) that the analysis of the word origin of Kompetenz (competence) leads to no unambiguous meaning, the etymological consideration of the substantive competencia provides clues to its conceptual characteristics (Müller-Ruckwitt, 2008). Figure 1 shows the satellite system ${ }^{3}$ for the concept of competence. In the central node is the most important concept, competence, which is surrounded by related concepts (Nuopponen, 1998: p. 180).

The basic meaning of competence is to be seen in "coincide/coincidence": Two dimensions to be determined correlate. With the concept of competence states or characteristics in abstract form are designated as a fit between two dimensions. The type of fit is expressed in equivalence and suitability. These relationships show that the dimensions enhance each other or agree, respectively the one dimension is suitable for the other, necessary, appropriate.

Description of higher-level concept and differentia specifica of competence of definitions of 10 selected articles.

To develop the characteristic matrix we compiled the higher-level concepts and the respective differentia specifica of the selected definitions.

First, we extracted the terms of the higher-level concepts and the differentia specifica from each article for the respective terms competence and compétence.

Second, in a characteristic matrix (Nuopponen, 1998) the higher-level concept and the respective characteristics were entered.

Table 4 summarizes the higher-level concepts captured with the aid of the characteristic matrix. We identified the high-level concepts of each definition and the respective differentia specifica of each higher level concept.
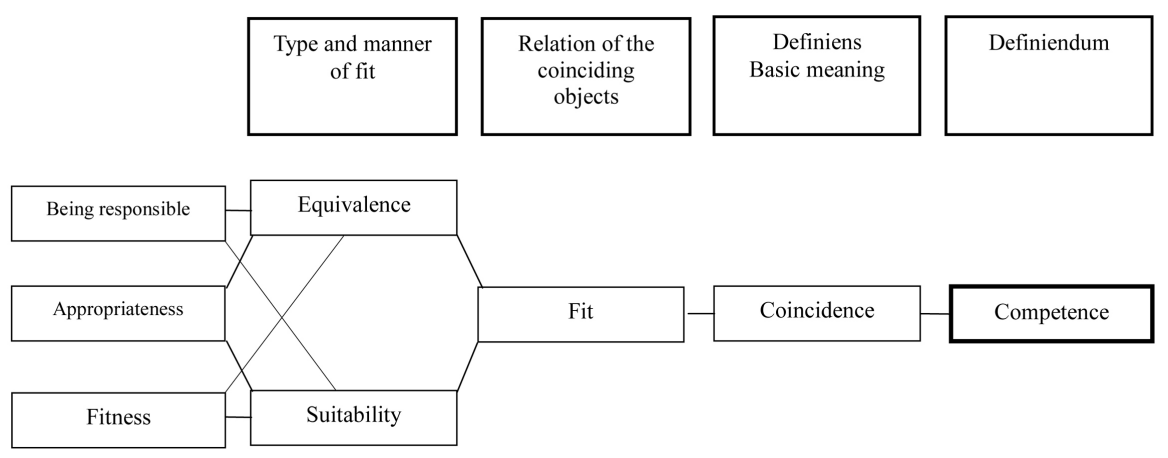

Figure 1. Satellite system on the etymologically reconstructed study material for the concept of "competence". Source: Own analysis.

${ }^{3}$ Nuopponen (1998: p. 180) developed the satellite system in connection with conceptual analysis. 
Table 4. Synthesis of generic or higher-level concept and differentia specifica of competence.

\begin{tabular}{|c|c|c|}
\hline Authors/Year & $\begin{array}{l}\text { Higher-level } \\
\text { concept }\end{array}$ & Characteristics \\
\hline $\begin{array}{l}\text { Blömeke et al. } \\
\text { (2015: p. 7) } \\
\text { Jacques } \\
\text { (2016: p. 161) }\end{array}$ & $\begin{array}{l}\text { Process or } \\
\text { Continuum } \\
\text { Processus }\end{array}$ & $\begin{array}{l}\text { To connect } \\
\text { between cognition and volition-affect-motivation } \\
\text { on the one hand and performance on the other } \\
\text { hand } \\
\text { "de mediation entre l'intentionnalité des } \\
\text { individus, leurs ressources et celles de leur } \\
\text { environment". } \\
\text { [of mediation between intentionality of the } \\
\text { individuals, their resources and those of their } \\
\text { environment] }\end{array}$ \\
\hline $\begin{array}{c}\text { Eraut } \\
\text { (1998: p. 135) }\end{array}$ & Ability & $\begin{array}{l}\text { To perform } \\
-\quad \text { tasks and roles } \\
\text { - } \quad \text { according to expected standards }\end{array}$ \\
\hline $\begin{array}{l}\text { Fernandez et al. } \\
\text { (2012: p. 363) }\end{array}$ & $\begin{array}{l}\text { Integration and } \\
\text { combination }\end{array}$ & $\begin{array}{l}\text { Of resources (internal and external) } \\
\text { deployed into action }\end{array}$ \\
\hline $\begin{array}{l}\text { Hager \& Gonczi } \\
\text { (1996: p. 16) }\end{array}$ & Relation & $\begin{array}{l}\text { Between abilities/capabilities and completion of } \\
\text { task }\end{array}$ \\
\hline $\begin{array}{c}\text { Klieme et al. } \\
\text { (2008: p. 9) } \\
\text { Weinert (1999: p. 3) }\end{array}$ & $\begin{array}{l}\text { Construct } \\
\text { Disposition }\end{array}$ & $\begin{array}{l}\text { Of disposition } \\
-\quad \text { Learnable } \\
-\quad \text { Contextualized } \\
\text { - } \quad \text { Cognitive } \\
\text { Performance disposition } \\
\text { - } \quad \text { Learned } \\
\text { - } \quad \text { Cognitive } \\
\text { - } \quad \text { Demand specific } \\
\text { - } \quad \text { Integrated } \\
\text { - } \quad \text { Content-related clusters of knowledge, skills } \\
\text { and attitudes } \\
\text { - Conditional for sustainable effective } \\
\quad \text { performance (including problem solving, } \\
\quad \text { realizing innovation, and creating } \\
\quad \text { transformation) } \\
\text { in a certain context, profession, organization, } \\
\text { job, role and situation. }\end{array}$ \\
\hline Short (1985: p. 5) & $\begin{array}{l}\text { Quality or state } \\
\text { of being }\end{array}$ & Of a person \\
\hline $\begin{array}{c}\text { Velde } \\
\text { (1999: p. 443) }\end{array}$ & $\begin{array}{l}\text { Conception and } \\
\text { relationship }\end{array}$ & $\begin{array}{l}\text { Of work } \\
\text { embedded in context }\end{array}$ \\
\hline
\end{tabular}

Source: Own analysis.

\subsection{Formulating the Conceptual Problem $P$}

The overview of the categories of definitions confirms that a consensus on the nature of the higher-level concept and the components is lacking (Fernandez et al., 2012). The literature reveals that not all authors define the characteristics, such as in the case of ability or capability, and that different characteristics of one definition display conceptual overlap, such as for example the characteristics 
situation and context. Some authors demarcate neither the generic concept nor the differentia specifica from concepts on the same conceptual level, as we find in the case of ability. A few higher-level concepts, such as, e.g., quality versus process, are complementary concepts. The analysis shows that the concept of competence is ambivalent.

Below we analyze the existence of the respective conceptual relations in implicit conceptual theory in the sense of Detection Analysis. We reviewed higher-level concepts and features of the identified definitions of Table 3 that were gained by systematic literature review. The first section groups together higher-level concepts that understand competence as ability/capability. We also analyze the understanding of competence defined as disposition in another section. The respective remaining sections discuss the higher-level concepts process, relation, quality or state of being and integration and combination of resources.

\subsubsection{Competence as Ability/Capability}

Eraut (1998) understands by competence ability to perform tasks and roles according to expected standards. Eraut (1998) specifies ability with the activities "to perform tasks and roles." "There are thus as many different abilities as there are tasks ...” (Lohman, 2012: p. 87).

Eraut's (1998) method of defining competence cannot be reconstructed, because the author gives no arguments for the determining characteristics. The question arises of why the author chose roles or tasks and not, for example, "action types" (Thomann, 2010): Action types "arise from a concrete action through the deletion of one or more concrete components of the action, e.g., the agent ..." (Thomann, 2010: p. 22). The "and" implies that not only tasks but also roles are to be performed in accord with expected standards. It is counterintuitive to exclude with the choice of the concept of tasks the creation of new things in the area of competence, because by tasks mental demands are understood, for the mastery of which methods are known (Dörner, 1976).

Ernaut (2016) clarifies competence through the action type "to perform tasks and roles according to expected standards". The quality of the ability is determined according to the extent to which performance standards were fulfilled.

Mulder (2011) defines competence as "capability to perform effectively". The author equates the concept of capability with that of ability: "The meaning of the concept is mostly defined as being able to perform effectively" (p. 12). This definition displays a nearness to that of White (1959), and Mulder (2011) sees this as dominant in the numerous definitions (p. 12).

Unclear in both definitions is what distinguishes ability from competence in the case of the choice of an action type (cf. also Wilhelm \& Nickolaus, 2013), for to Thomann (2010) the ascription of an ability implies that an “... agent $\alpha$ [can] then exactly perform actions of type $h$, if under such circumstances which are appropriate for carrying out actions of type $h, a$ normally successfully carries out actions of type $h$ " (Thomann, 2010: p. 22). 
Mulder (2011) specifies the generic concept as an "integrated set of capabilities" (p. 13). This definition is vague, because it is unclear what we should understand by set and integrated. By competence is understood an integrated set of capabilities that arises from clusters of knowledge, skills and attitudes. That this cluster is a condition for effective performance is not explained. In addition, the conditioning factors are not a definitional characteristic of competence, since they give no answer to the question of what a competence is (Roeger, 2016). The definition is also vague insofar as the action type with the part components "problem solving", "realizing innovation", and "creating transformation", is not derived. "Knowledge", "skills" and "attitudes" are not coordinated concepts, as the arrangement implies: Attitudes are for Guilford (1959) coordinated with abilities, not skills. It is unclear why the author gives conditions for the definition that must be met in order that effective performance can be realized. As explained under ability, in this definition as well it is open what distinguishes capability from competence.

In both definitions, the entities that are called abilities are actions. The suitable expression would be "action type" (Thomann, 2010), for an essential characteristic is that it is not a matter of " ... $\alpha$ can perform a specific action, ..., but rather of such statements with which $\alpha$ is ascribed the ability to perform well actions of a specific sort" (Thomann, 2010: p. 22).

As, "the question: 'competent for (doing) what?' is essential to any competence definition" (Klieme et al., 2008: p. 7) and the entities which are called abilities are actions, the higher-level concept of ability is plausible.

\subsubsection{Competence as Disposition}

Not only Weinert (1999) but also Klieme et al. (2008) understand competence as a disposition. Klieme subordinates the disposition concept to a further higher-level concept, that of construct: "The expression emphasizes that with competences it is a matter of something 'constructed' by scientists that can at most be indirectly empirically interpreted ... and that is not, like observational concepts, directly related to visible objects". (Schroeder-Heister, 1995: p. 445) The construct is deducible on the basis of observable indicators.

The conceptual clarifications of Weinert (1999) and Klieme et al. (2008) include no definition of the concept of disposition. Roeger (2016: p. 125) thinks a disposition refers to a characteristic "that is manifest only under specific conditions".

In the definition of Klieme et al. (2008) the concept of disposition is clarified in that it is learnable, contextualized and cognitive. The definition gives a conjunction of these three attributes. With regard to learnability, it can be affirmed with Roeger (2016: p. 157) that the concept of competence is trivialized by this characteristic, "... since then every person is competent who does not dispose of a competence, but can in principle learn it". The determination of the second necessary characteristic contextualized is vague, because it is unclear which external factors of the interaction to which the context per definition refers, how, 
e.g., place and time, must in what way be present, so that a disposition is contextualized. Likewise, with Klieme et al. (2008) cognitive characteristics distinguish the disposition.

Weinert (1999) specifies the disposition as a performance disposition and operationalizes this as learned, cognitive and demand specific. A performance disposition leads under specific conditions to a manifestation of prototypical psychic processes that are distinguished by specific quality criteria.

Weinert (1999) employs the concept learned in a more precise manner, because the area of application is limited: A competence is only present if it is learned. There is also a difference in the differentia specifica between contextualized and demand specific.

Due to the high level of abstraction, human dispositions such as, for example, perseverance and open-mindedness (Splitter, 2010: p. 216) are seen as vague in terms of their behavioral verification. It could be argued that it is not operable to further differentiate these forms depending on the context, because there might be as many dispositions as demands.

Following a definition of the theoretical perspective of situated cognition, ability is seen as "a joint property of the union of person and environment." (Lohman, 2012: p. 89) Against this theoretical background, the definition of competence appears to be circular, because the component of the environment already reflects, according to Snow (1994) who refers to Gibson (1979: p. 28), "the invitation, demand, or opportunity structure of a situation".

To mark the difference between disposition and competence, inspired by Tishman et al. (1993), we could ask: Does he philosophize? This question refers to the inclination to philosophize (Splitter, 2010), not to the competence.

\subsubsection{Competence as a Process}

According to Blömeke et al. (2015: p. 7) and Jacques (2016: p. 161), the concept of competence refers to a process ("processus") or a continuum. By a process is understood a directed process of an event (Carrier \& Wimmer, 1995: p. 385), while a continuum means something cohesive and continuous.

Blömeke et al. (2015: p. 7) specify a process with "connect" and Jacques (2016: p. 161) with "mediate". Even if the authors name the objects of the process, they are not precise: What does "connect" mean "between cognition and volition-affect-motivation on the one hand and performance on the other hand" or "mediate" specifically between the intentionality of individuals, their resources and those of their environment? Blömeke et al. (2015) present more a model of a continuum than one of a process showing that some dispositions of cognition or motivation are the prerequisites to acquire situation-specific skills needed for performance.

The concept of competentia cannot be understood as a process, because the suffix-ia as an abstraction of nominibus (Düntzer, 1879: p. 252) does not depict an event nominalization. If competentia is understood as a verbal abstraction, as a derivative of the participle (Eykmann, 2016: p. 34), there is a state or result 
nominalization (von Heusinger, 1998: p. 7), as in the case of appropriateness or of coming together. According to von Heusinger (1998), we cannot unambiguously semantically distinguish between characteristic and state nominalization: "Characteristics express attributes that are inherent or long lasting, while states are less enduring or stable. Formally in general we speak with the formation of adjectives of characteristic abstractions or characteristic nominalizations and with the formation of verbs of state abstractions or nominalizations" (von Heusinger, 1998: p. 4).

\subsubsection{Competence as a Relation}

Hager and Gonczi (1996: p. 16) define competence as a relation between abilities/ capabilities and the completion of a task. The ascription of an ability that an

“... agent $\alpha$ [can] exactly then perform actions of type $h$, if under such circumstances that are suitable for performing actions of type $h, \alpha$ can normally successfully perform actions of type $h^{\prime \prime}$ (Thomann, 2010: p. 22) is related to the result of a concrete task. If the normally successful performance of actions of a specific type is related to that of a specific action of that type, then the second relatum would impermissibly be a component of the concept of the former.

The concept of relation, whose higher-level concept is that of structure, designates a relation or a relationship among several objects, an entity or event and one or more other entities or events. Since the authors make no statements on the character of the highly complex relation, the specification of this relation remains vague. It is moreover unclear whether the characteristics abilities and capabilities are connected with a conjunction or disjunction. In addition, Hager and Gonczi (1996) do not specify the difference between ability and capability. If one defines a relational concept, it is to be defined through reference to its relata, which was not done here. The under-specification of the definition also applies to the definition by Velde (1999: p. 443), who defines competence as a conception and relationship of work. The concept is defined by two higher-level concepts with different meanings that are neither derived nor defined.

With the characteristic of the relation, the concept of competence cannot be sufficiently defined, since no answer can be given to the question of what competence is.

\subsubsection{Competence as a Quality or State of Being}

From the view of a thesis by Short (1985) that competence is a quality or state of being, it can be seen that the definition of the concept through the disjunction-linked unreconstructable higher-level concepts of quality or state of being as the character is under-determined, since neither the characteristics of state of being nor quality are defined, nor is it clear when a state and when a quality is present.

The concept of competence is not made more precise, because Short (1985) introduces two incompatible higher-level concepts in the definition: While the state is affected by circumstances, quality is stable over time. "States are observed 
behaviours including reports of experiences that typically refer to a day or a few assessments during a day" (Asendorpf \& Motti-Stefanidi, 2018: p. 168). Short (1985: p. 5) himself sees the challenge in the holistic conceptualization, as it has to be understood in terms of the quality and not the sub-features of competence. If a state typically refers to a period of a day, then it is not an educationally meaningful category.

\subsubsection{Competence: Integration and Combination of Resources}

Fernandez et al. (2012) defines competence as a behavior of integrating and combining internal and external resources. The definition is under-determining, because the object of the activity, the resource is not determined. In addition, the actions of integrating and combining, which are not disjunctive, are neither theoretically derived nor specified. The authors see a further enhancement of the conceptual characteristic in naming the purpose of the activity and the resources: Competence is present when combined and integrated resources are prepared for an action. Since the suffix-ia (in competentia) does not permit deriving a behavior from the word competence, the higher-level concept of behavior is inappropriate.

The analysis of definitions shows that it is not a trivial aspect to find the higher-level concept of the concept of competence and its specific difference. For theoretical concepts it holds that depending on theoretical perspective, the theoretical presuppositions of the definition are different.

\subsection{Stating the new conceptual relation $R$}

Embedded within the etymological reconstruction, we refer to the logical conceptual systems of educational science and psychology and to representative philosophical analyses to state the new conceptual relation of competence.

The etymological reconstruction produced the result that with the concept of competence states or characteristics in abstract form are designated as a fit between two dimensions that complement or match each other, or respectively that the one dimension is suitable, necessary or appropriate for the other.

We were able to show that certain relations

- competence as a process

- competence as a relation

- competence as a state

- competence as integration and combination of resources

don't hold among concepts of the etymology and the language of educational science and psychology. Based on the logical conceptual systems of educational science and psychology and against the background that some relations between the concepts were not clarified within the definitions, we came to a preliminary result: The following meanings of the concept of competence against our explained theoretical presuppositions of the definitions are plausible: construct, quality, and ability.

Referring to representative philosophical analyses, competence is understood 
- "subject-specific skill to fulfill reliably subject-specific demands under normal conditions" (Roeger, 2016: p. 159), and/or

- “attribution" (Hügli, 2016: p. 14).

According to Constructive Analysis, the new relation R is postulated (Kosterec, 2016: p. 222).

(R) Competence for performing domain-specific actions of type $h$ is the cognitive ability to normally successfully perform domain-specific actions of type $h$ under circumstances that are suitable for domain-specific actions of type $h$.

The concept of ability which is the higher-level concept of competence was defined with reference to Thomann (2010).

\subsection{Formulating tests $\mathrm{T}$ of the conceptual relation $\mathrm{R}$ within $\mathrm{CB}$}

The following tests were carried out to examine the proposed operational definition:

- Linguistic usage is examined for the proposed definition.

- In order to clarify the structure of the substantive conceptual system it is analyzed whether the higher-level concept and the differentia specifica are substantively unambiguous.

- In order to identify logical errors, it is examined whether 1) higher-level concepts are logically related to other concepts on the same level and 2) concepts on the level of the differentia specifica that are suspected to be coordinated are coordinated.

\subsection{Elaborating the new relation $\mathrm{R}$ by tests $\mathrm{T}$ respecting $\mathrm{CB}$}

The linguistic and scientific usage shows that the concept of competence is a relational concept, competent for (doing) what (Klieme et al., 2008), which has an inherent reference point. The reference to its relation must be defined. Together with the etymological derivation goes that relational concepts are mostly verbal abstractions or abstractions from adjectives.

Because the entities which are called abilities can only be individuated through reference of types of actions (Thomann, 2010: p. 22), the higher-level concept of the definition of competence (competent for doing what) is accordingly that of ability. As a definition for the concept of practical abilities, Thomann (2010: p. 22) proposes the following: "An agent $\alpha$ can exactly then perform actions of type $h$, if $\alpha$ can normally successfully perform actions of type $h$ under circumstances that are appropriate for performing actions of type $h "$ ". Thomann also transfers the operational definition to cognitive abilities, because the difference between mental and non-mental abilities is "that the realization or respectively performance of the former requires no bodily activity" (Thomann, 2010: p. 41). "Mental action types appear to be partially characterizable through their success criteria, as well as for the circumstances appropriate for their realization, just as are action types whose realization contains bodily activity" (Tho- 
mann, 2010: p. 41). Thomann's definition (2010) will be adopted here for the concept of ability.

As we have already established above with Thomann (2010), in the case of ability it is not a matter of a specific action, but rather of an action type $h$ which forms the inherent reference point of the relational concept of competence.

Actions can refer to a single performance of an action or a group of actions. The unity of an action consists in that individual performance or group of actions have one and the same purpose or respectively goal.

Referring to natural language, typically the concept of competence is not generally used. The following examples illustrate this linguistic usage: Linda disposes of mathematical competences. John is competent in philosophy. According to this usage and to philosophical analyses, the concept of competence refers to an area, a specific subject (Roeger, 2016), to a domain. We follow Hirschfeld and Gelman (1994: p. 21) to define the term domain: "a domain is a body of knowledge that identifies and interprets a class of phenomena assumed to share certain properties and to be of a distinct and general type".

Circumstances are appropriate precisely "if a failure cannot be excused by reference to unfavorable conditions" (Thomann, 2010: p. 24). Various types of action require different circumstances for their realization (Thomann, 2010).

The concept of normalcy is likewise a relative concept. It refers to the reliability of successful performance, because abilities do not offer any success guarantee (Thomann, 2010: p. 26). "When an action is normally (italics in original K.S.) carried out successfully, it thereby does not seem to be susceptible to quantification, but rather to vary from one action type to another" (Thomann, 2010: p. 27).

The higher-level concept of ability is logically related to other concepts located on the same level. For example, Guilford (1959: p. 9) subdivides all personality characteristics into classes with the following personality domains: Physiology, needs, interests, attitudes, temperament, abilities and morphology.

Neyer and Asendorpf (2018) subsume under the construct of ability intelligence, creativity, social and emotional competence. The concepts of intelligence and social competence are located on the same hierarchical level, although they have different conceptual ranges. Even if these four abilities are demarcated in everyday psychology, clarity is lacking about some constructs, such as for example creativity (Neyer \& Asendorpf, 2018) and criteria of classification.

In contrast to Neyer and Asendorpf (2018), we understand competence like Klieme et al. (2008); occasionally Weinert, 1999) as cognitive ability.

We exclude motivational, volitional and emotional components from competence. Roeger (2016) argues in this regard that free will and motivation with its action grounds should be protected from pedagogical influences. It is counter-intuitive to deny someone has competence, if they have no desire to play the piano. Motivation and volition enhance competence so that performance comes about, they do not however constitute competence (Roeger, 
2016).

Ability as a higher-level concept is subdivided at least into cognitive and practical ability (cf. Thomann, 2010). The element of the already made division of cognitive ability is dichotomously subdivided on the basis of the essential characteristic of domain specificity into the sub-concepts of domain specificity and domain-non-specificity. The subsumable concept of competence comprehends all characteristics of the concept of cognitive ability and additionally as specifying characteristic domain specificity. For the concept of cognitive ability that is distinguished by a domain-non-specificity we have so far not found any suitable concept. The concepts are coordinated, because in contrast only a classificatory criterion was simultaneously employed on the same level of abstraction of the logical conceptual system (Peltoniemi, 2007: p. 254).

In contrast to the philosophical analysis of Roeger (2016), we do not use as a higher-level concept of competence that of skill ("Fertigkeit"): With reference to action regulation theory according to Hacker (1998), for example, skills represent action on the level of senso-motoric regulation.

\subsection{If the relation $R$ succeeds in tests, declaring it a part of $C B$}

As a newly postulated relation $\mathrm{R}$ succeeded in the previously conducted tests, we have made it part of the conceptual background (CB).

\section{Discussion and Conclusions}

Following the constructivist viewpoint (Stoof et al., 2002), there may be no objective criteria in selecting a definition. Accordingly, competence is conceived as a construct. However, the etymological reconstruction, the logical conceptual systems of educational science and psychology and representative philosophical analyses provide a framework from which to derive the new conceptual relation of competence:

Competence for performing domain-specific actions of type $h$ is the cognitive ability to normally successfully perform domain-specific actions of type $h$ under circumstances that are suitable for domain-specific actions of type $h$.

The higher-level concept of competence is ability, which refers to cognitive ability and is distinguished by domain-specificity. The concept of ability is logically related to other concepts located on the same level. We differentiate cognitive ability at least from practical ability and specify the cognitive according to domain-specific competence, and domain-non-specific ability. These two sub-concepts are coordinated, because they are only distinguished by the criterion of domain-specificity.

The etymological reconstruction produced the result that with the concept of competence characteristics in abstracted form are designated as a fit between two dimensions: in the case of competence, it is a matter of a coming together as the equivalent of a normally successful performance of a type of state changes (ability), on the one side, and the changes of state (demands) set from outside to 
be brought about, on the other. By actions Thomann (2010: p. 147) understands "state transitions (italics in original-K.S.) whose occurrence is directly attributable to an agent". Thereby, it is irrelevant for Thomann (2010: p. 147) "whether the state changes actually are the concrete actions or are merely brought about by them".

The results we have summarized have interesting implications for theories of competence from the perspective of educational science. The innovative way of defining the concept of competence proposed within this study lays a foundation for operationalizing the construct of competence. From the functional-psychological viewpoint competence focuses on the ability of a person to manage demands. However, the results of this study would suggest that competence also fulfills a purpose of development. Agency succeeds through domain-specific learning: Leslie (1994) showed this effect for early childhood. It can be demonstrated that the development of competence reinforces agency as a disposition.

The unity of an action consists in that individual performances of a group of action types have one and the same purpose. It remains, with Thomann (2010: p. 42), to examine "whether for every cognitive ability $k$ there is a number $H$ of-practical or mental-action types, so that an agent must include every type of action from $\mathrm{H}$ in his abilities in order to also have mastered $k$ '.

Since the concepts appearing in the definiens must be more elementary than the definiendum, the question arises of how the concept of domain-specificity can be defined in a more elementary way.

Understanding ability as situated within an interactionist theoretical perspective (Snow, 1994) means that interest, attitudes, needs, are likewise to be demarcated as situated in a further step against non-situated characteristics like physiology and morphology. From an interactionist point of view, domain-specificity is a "joint property of the union of person" (Lohman, 2001: p. 89) and phenomenon.

We see a limit of our conceptual framework despite the contradictory opposition of domain-specific and domain-non-specific in the empirical gradual approach on the level of differentia specifica.

This conceptual analysis is far from final. However, we believe that this framework is useful for analyzing the concept of competence.

\section{Conflicts of Interest}

The author declares no conflicts of interest regarding the publication of this paper.

\section{References}

Ashworth, P. D., \& Saxton, J. (1990). On “Competence”. Journal of Further and Higher Education, 14, 3-25. https://doi.org/10.1080/0309877900140201

Asendorpf, J. B., \& Motti-Stefanidi, F. (2018). Mediated Disposition-Environment 
Transactions: The DAE Model. European Journal of Personality, 32, 167-185. https://doi.org/10.1002/per.2118

Behse, G. (1976). [Art.] Kompetenz. In J. Ritter, \& K. Gründer (Eds.). Historisches Wörterbuch der Philosophie (Columns 918-933). [Completely Revised Edition of the Wörterbuch der Philosophischen Begriffe by Rudolf Eisler] (Vol. 4). Stuttgart: Wissenschaftliche Buchgesellschaft.

Blömeke, S., Gustafsson, J.-E., \& Shavelson, R. J. (2015). Beyond Dichotomies Competence Viewed as a Continuum. Zeitschrift für Psychologie, 223, 3-13. https://doi.org/10.1027/2151-2604/a000194

Boyatzis, R. E. (2008). Competencies in the 21st Century. The Journal of Management Development, 27, 5-12. https://doi.org/10.1108/02621710810840730

Boyatzis, R. E. (1982). The Competent Manager. A Model for Effective Performance. New York: John Wiley \& Sons.

Carrier, M., \& Wimmer, R. (1995). Prozeß. In J. Mittelstraß (Ed.), Enzyklopädie Philosophie und Wissenschaftstheorie (pp. 385-387). Stuttgart, Weimar: Metzler.

Chomsky, N. (1965). Aspects of the Theory of Syntax. Cambridge, MA: MIT Press.

Dörner, D. (1976). Problemlösen als Informationsverarbeitung (2nd ed.). Stuttgart: Kohlhammer.

Düntzer, H. (1879). Die lateinischen Suffixe tia, tio. Rheinisches Museum für Philologie, Band 34, 245-259.

Eraut, M. (1998). Concepts of Competence. Journal of Interprofessional Care, 12, 127-139. https://doi.org/10.3109/13561829809014100

Eykmann, W. (2016). Wider die Kompetenzen in Schule und Hochschule. Cursor Latein4EU. Zeitschrift für Freunde der lateinischen Sprache und europäischen Kultur, $12,34-38$

Fernandez, N., Dory, V., Ste-Marie, L.-G., Chaput, M., Charlin, B., \& Boucher, A. (2012). Varying Conceptions of Competence: An Analysis of How Health Sciences Educators Define Competence. Medical Education, 46, 357-365. https://doi.org/10.1111/j.1365-2923.2011.04183.x

Fügemann, M. W. (2004). Zuständigkeit als organisationsrechtliche Kategorie. In K. Stern, \& P. J. Tettinger (Eds.), Studien zum Öffentlichen Recht und zur Verwaltungslehre. Munich: Verlag Vahlen.

Gibson, J. J. (1979). The Ecological Approach to Visual Perception. Boston, MA: Houghton Mifflin.

Guilford, J. P. (1959). Personality. New York: McGraw-Hill.

Hacker, W. (1998). Allgemeine Arbeitspsychologie. Psychische Regulation von Arbeitstätigkeiten (4th ed.). Berlin: Huber.

Hager, P., \& Gonczi, A. (1996). What Is Competence? Medical Teacher, 18, 15-18. https://doi.org/10.3109/01421599609040255

Hartig, J. (2008). Kompetenzen als Ergebnisse von Bildungsprozessen. In N. Jude, J. Hartig, \& E. Klieme (Eds.), Kompetenzerfassung in pädagogischen Handlungsfeldern. Theorien, Konzepte und Methoden (pp. 15-26). Berlin: BMBF.

Hartig, J., \& Klieme, E. (2006). Kompetenz und Kompetenzdiagnostik. In K. Schweizer (Ed.), Leistung und Leistungsdiagnostik (pp. 127-143). Berlin: Springer. https://doi.org/10.1007/3-540-33020-8_9

Von Heusinger, K. (1998). Abstraktnominalisierungen im Deutschen. Eine Bildungsgeschichte. Arbeitspapier 94. Fachgruppe Sprachwissenschaft. Konstanz: 
Universität Konstanz.

Hirschfeld, L. A., \& Gelman, S. A. (1994). Toward a Topography of Mind: An Introduction to Domain Specificity. In L. A. Hirschfeld, \& S. A. Gelman (Eds.), Mapping the Mind. Domain Specificity in Cognition and Culture (pp. 3-35). Cambridge: Cambridge University Press. https://doi.org/10.1017/CBO9780511752902.002

Hoffmann, T. (1999). The Meanings of Competency. Journal of European Industrial Training, 23, 275-286. https://doi.org/10.1108/03090599910284650

Hügli, A. (2016). Was ist Kompetenz? Begriffsgeschichtliche Perspektiven eines pädagogischen Schlagwortes. Lvb Inform, 17, 12-22.

Jacques, J. (2016). Définition des compétences propres à l'organisation des collections d'informations personnelles numériques. Dissertation doctorale présentée en vue de l'obtention du grade de docteur en information et communication. Université catholique de Louvain.

Klieme, E., \& Hartig, J. (2008). Kompetenzkonzepte in den Sozialwissenschaften und im erziehungswissenschaftlichen Diskurs. In M. Prenzel, I. Gogolin, \& H. H. Krüger (Eds.), Kompetenzdiagnostik (pp. 11-29). Berlin: Springer.

https://doi.org/10.1007/978-3-531-90865-6_2

Klieme, E., Hartig, J., \& Rauch, D. (2008). The Concept of Competence in Educational Contexts. In J. Hartig, E. Klieme, \& D. Leutner (Eds.), Assessment of Competencies in Educational Contexts (pp. 3-22). Ashland, OH: Hogrefe \& Huber Publishers.

Kosterec, M. (2016). Methods of Conceptual Analysis. Filozofia, 71, 220-230.

Leslie, A. M. (1994). ToMM, ToBy, and Agency: Core Architecture and Domain Specificity. In L. A. Hirschfeld, \& S. A. Gelman (Eds.), Mapping the Mind. Domain Specificity in Cognition and Culture (pp. 119-148). Cambridge: Cambridge University Press. https://doi.org/10.1017/CBO9780511752902.006

Lohman, D. F. (2012). Issues in the Definition and Measurement of Abilities. In J. M. Collis, \& S. Messick (Eds.), Intelligence and Personality. Bridging the Gap in Theory and Measurement (pp. 79-98). Hillsdale, NJ: Erlbaum.

Mitchelmore, S., \& Rowley, J. (2010). Entrepreneurial Competencies: A Literature Review and Development Agenda. International Journal of Entrepreneurial Behavior \& Research, 16, 92-111. https://doi.org/10.1108/13552551011026995

Moore, D. R., Cheng, M. I., \& Dainty, A. R. J. (2002). Competence, Competency and Competencies: Performance Assessment in Organizations. Work Study, 51, 314-319. https://doi.org/10.1108/00438020210441876

Müller-Ruckwitt, A. (2008). "Kompetenz": Bildungstheoretische Untersuchungen zu einem aktuellen Begriff. Würzburg: Ergon-Verlag.

Mulder, M. (2011). The Concept of Competence: Blessing or Curse? In I. Torniainen, S. Mahlamäki-Kultanen, P. Nokelainen, \& P. Ilsley (Eds.), Innovations or Competence Management (pp. 11-24). Lahti: Lahti University of Applied Sciences.

Neyer, F. J., \& Asendorpf, J. B. (2018). Psychologie der Persönlichkeit (5th ed.). Berlin: Springer Verlag. https://doi.org/10.1007/978-3-662-54942-1

Norris, N. (1991). The Trouble with Competence. Cambridge Journal of Education, 21, 331-341. https://doi.org/10.1080/0305764910210307

Nuopponen, A. (1998). Begriffsbeziehungen und Begriffssysteme. In C. Laurén, J. Myking, \& H. Picht (Eds.), Terminologie unter der Lupe. Vom Grenzgebiet zum Wissenschaftszweig (pp. 164-185). Vienna: TermNet, Internat. Network for Terminology. 
OECD (2002). Definition and Selection of Competencies. DeSeCo, Theoretical and Conceptual Foundations: Strategy Paper. DEELSA/ED/CERI/CD(2009)9.

Peltoniemi, P. (2007). Begriffsanalyse als Untersuchungsmethode. In N. Niemelä, \& E. Lehtinen (Eds.), Übersetzungstheorie, Fachsprachen und Mehrsprachigkeit (pp. 248-259). Publikationen der Studiengruppe für Fachsprachenforschung, Übersetzungstheorie und Mehrsprachigkeit an der Universität Vaasa. Nr. 34. Vaasa: Universität Vasa.

Roeger, C. (2016). Philosophieunterricht zwischen Kompetenzorientierung und philosophischer Bildung. Reihe: Wissenschaftliche Beiträge zur Philosophiedidaktik und Bildungsphilosophie Vol. 2. Opladen, Berlin, Toronto: Verlag Barbara Budrich. https://doi.org/10.2307/j.ctvddzfrz

Schmidt, P. (1999). [Art.] competo und competentia. In O. Prinz (Ed.), Mittellateinisches Wörterbuch (Vol. 3, Columns 1055-1058 Respectively 1055). Munich: Beck.

Schroeder-Heister, P. (1995). Konstrukt. In J. Mittelstraß (Ed.), Enzyklopädie Philosophie und Wissenschaftstheorie (Vol. 2, p. 445). Stuttgart, Weimar: Metzler.

Short, E. C. (1985). The Concept of Competence: Its Use and Misuse in Education. Journal of Teacher Education, 36, 2-6. https://doi.org/10.1177/002248718503600202

Snow, R. E. (1994). Abilities in Academic Tasks. In R. J. Sternberg, \& R. K. Wagner (Eds.), Mind in Context: Interactionist Perspectives on Human Intelligence (pp. 3-37). Cambridge: Cambridge Univ. Press.

Splitter, L. J. (2010). Dispositions in Education: Nonentities Worth Talking about. Educational Theory, 60, 203-230. https://doi.org/10.1111/j.1741-5446.2010.00354.x

Stoof, A., Martens, R. L., Van Merienboer, J. J. G., \& Bastiaens, T. J. (2002). The Boundary Approach of Competence: A Constructivist Aid for Understanding and Using the Concept of Competence. Human Resource Development Review, 1, 345-365. https://doi.org/10.1177/1534484302013005

Thomann, M. (2010). Die Logik des Könnens. Inaugural-Dissertation zur Erlangung der Doktorwürde der Philosophischen Fakultät der Rheinischen Friedrich-WilhelmsUniversität zu Bonn. (Series: Logische Philosophie) Berlin: Logos Verlag.

Tishman, S., Jay, E., \& Perkins, D. N. (1993). Teaching Thinking Dispositions: From Transmission to Enculturation. Theory into Practice, 32, 147-153. https://doi.org/10.1080/00405849309543590

Velde, C. (1999). An Alternative Conception of Competence: Implications for Vocational Education. Journal of Vocational Education and Training, 51, 437-447. https://doi.org/10.1080/13636829900200087

Walde, A. (1954). Lateinisches Etymologisches Wörterbuch (3rd ed.). Heidelberg: Carl Winters Universitätsbuchhandlung.

Weinert, F. E. (1999). Concepts of Competence (pp. 3-34). Contribution within the OECD Project Definition and Selection of Competencies: Theoretical and Conceptual Foundations (DeSeCo). Neuchâtel: Bundesamt für Statistik.

White, R. W. (1959). Motivation Reconsidered: The Concept of Competence. Psychological Review, 66, 297-333. https://doi.org/10.1037/h0040934

Wilhelm, O., \& Nickolaus, R. (2013). Was grenzt das Kompetenzkonzept von etablierten Kategorien wie Fähigkeit, Fertigkeit oder Intelligenz ab? Zeitschrift für Erziehungswissenschaft, 16, 23-26. https://doi.org/10.1007/s11618-013-0380-6 